\title{
Progression og underviserkompetencer
}

\author{
Lene Tortzen Bager, ph.d. og lektor, Center for Undervisningsudvikling og Digitale \\ Medier, Aarhus Universitet.
}

\section{Reviewet artikel}

På baggrund af en kvalitativ interviewundersøgelse af undervisere ved Aarhus Universitet lavet i 2012, tematiserer artiklen, hvordan undervisere udvikler deres faglige og pædagogiske kompetencer i forhold til at kunne skabe progression inden for innovation og entreprenørskab forstået enten som didaktik, arbejdsformer i faglige forløb eller som fag på universitetet. I arbejdet med progression er det en udfordring at integrere de nye faglige dimensioner $i$ det kernefaglige felt.

Den seneste model for progression inden for innovation og entreprenørskab siger, at det er den lærendes generelle erfaringsniveau, der er den afgørende progressionsskabende faktor (Progressionsmodellen, Fonden for Entreprenørskab, 2013b). Samtidig skelner international forskning inden for studiekompetenceområdet mellem niveauer, hvor indlejret viden er det mest avancerede kompetenceniveau (Barrie, 2002).

Ifølge progressionsmodellen og den næunte kompetenceforskning er erfaring og dybt integreret læring altså centrale dimensioner $i$ progression. Men hoad er underviserens rolle heri? Underviserens professionelle udviklingsarbejde forekommer at være underbelyst i forhold til, at underviseren er den legitime garant for integrationen af nye faglige dimensioner og for den studerendes kompetenceniveau.

Interviewundersøgelsen forholder sig til spørgsmålet om progression gennem de deltagende underviseres beskrivelse af betydningslag i entreprenørskabsbegrebet koblet til de praksisformer i undervisningen, der knytter sig hertil samt et indblik i undervisernes refleksioner over deres kompetenceudviklingsprocesser. Artiklens bidrag til progression er at se underviserens motivation og kompetenceudvikling som forudsætninger herfor.

\section{Baggrund: Entreprenørskab}

Innovation og entreprenørskab er en tværgående faglig dimension i det danske uddannelsessystem. Der er, som det hedder, innovation og entreprenørskab Fra ABC til ph.d. (Fonden for Entreprenørskab/Young Entreprise Danmark, 2013a). Fra grundskole til universitet er der fokus på almene kompetencer som 'handling', 'kreativitet', 'omverdensforståelse' og 'personlig indstilling' (Fonden for Entreprenørskab/Young Entreprise Danmark, 2013b). De nævnte kompetencer bliver beskrevet som dimensi- 
oner i alle innovative og entreprenørielle læreprocesser. I den nye model for progression indenfor innovation og entreprenørskab er den lærendes erfaring med den type læreproces den afgørende og progressionsskabende faktor.

På universitetet skal kandidater opnå kompetencer til at fungere i komplekse kontekster og løse sammensatte problemstillinger gennem en dyb faglig viden og evnen til at koble sin viden på og åbne problemstillinger i samarbejde med andre faglige perspektiver. Det nye element i en problembaseret arbejdsmåde er, som den praktiseres på bl.a. Aalborg og Roskilde universiteter, at læringen er baseret på en kombination af faglige og personligt erfaringsbårne elementer, som rækker ud over det faglige. Det handler konkret om en personlig evne til at koble sig, åbne problemstillinger og være bevidst om egne resurser både fagligt og personligt (Bager \& Blenker, 2008).

Den forståelse taler meget godt sammen med forskning i akademiske studiekompetencer. I et studie af generiske studiekompetencer beskriver Barrie (2002) taksonomiske niveauer i kompetencer og dermed en mulig progression i studiekompetencer. På et grundlæggende niveau har den studerende kompetencer, der kan komplementere anden viden ('complement'), på et højere taksonomisk niveau kan den studerende anvende sin viden og udvikle sin forståelse af en ny disciplin herigennem ('translation'), på det mest avancerede niveau er den studerendes faglige forståelse og handlerum integreret i en personlig og faglig tilgang til verden ('enable/embedded').

Indtil nu ligger der i sagens natur mest følgeforskning inden for den innovations- og entreprenørskabsundervisning, der er længst tradition for. Den ligger på de ingeniøruddannelser, hvor kreativitet og konstruktion i forbindelse med produktudvikling har været en del af undervisningen de sidste mange år. Tilsvarende har de samfundsvidenskabelige fakulteter og handelsskolerne lang tradition for at undervise i entreprenørskab med henblik på iværksætteri og start af egen virksomhed. Inden for innovation og entreprenørskab, forstået bredere med henblik på at udvikle et 'mindset' for foretagsomhed og værdiskabelse, er der endnu ikke mange langtidsstudier, der viser effekten af denne form for undervisning. Men de første undersøgelser af en sammenlignende effekt i grundskolen viser, at undervisningsforløb med et mere teknisk, redskabsmæssigt sigte på iværksætteri skaber flere iværksættere. Mens undervisning med et bredere sigte på at ændre elevens handlekraft og omverdens- og selvforståelse ikke skaber flere iværksættere. Den undervisning skaber imidlertid mere 'school engagement' og får svagere elevgrupper med i undervisning og videre $\mathrm{i}$ uddannelsesforløb. Den mest afgørende faktor i den gruppe, hvor flere gennemfører uddannelse er 'teacher support'. ${ }^{1}$

\footnotetext{
${ }^{1}$ Resultaterne blev præsenteret af Kåre Moberg på Århus Erhvervsakademi 26. juni 2013, hvor Fonden for Entreprenørskab/Young Enterprise Danmark var vært.
} 
Progressionen i innovative og entreprenørielle kompetencer ligger således hos den studerende i dennes faglige og personlige erfaringer, men i udbygningen af erfaringer og i understøttelsen af dem er underviseren den mest centrale faktor.

\section{Undersøgelse og metode}

I denne artikel vil jeg belyse, hvordan undervisere indarbejder nye faglige elementer og didaktiske dimensioner i deres undervisningspraksis. Baggrunden herfor er en interviewundersøgelse lavet med fem undervisere fra forskellige fag på Arts, Aarhus Universitet. Interviewene blev gennemført i maj og juni 2012 i samarbejde med studerende ved Pædagogisk Antropologi, Anna Hollyoak Frederiksen.

Der lå ingen særlige kriterier til grund for udvælgelsen af deltagere. Hvis der var blevet stillet krav til undervisernes entreprenørskabsbegreb, deres faglige spredning, køn eller anciennitet, ville der ikke være nogen at vælge ud iblandt, for der er stadigvæk meget få undervisere på Arts, der arbejder med entreprenørskab som dimension i deres undervisning. Derfor valgte vi at interviewe de undervisere, der var, og bruge deres erfaringer og beskrivelser til at vise, hvordan entreprenørskab udvikler sig som undervisningspraksis.

Hensigten med undersøgelsen var at udforske hvilke betydninger af begrebet entreprenørskab, der er på spil i undervisningen, og videre at tegne et billede af entreprenørskab, som det praktiseres for tiden. Interviewmaterialet er ikke repræsentativt, men det afspejler de fem underviseres holdninger og refleksioner. Materialets bidrag er, at det giver adgang til at kigge ind i underviseres eksperimentelle arbejde med at integrere entreprenørskab som en ny faglig dimension og praksis i undervisningen.

En interviewguide blev fremsendt sammen med invitation til at deltage. Selve interviewet foregik som et semistruktureret interview af ca. 1,5 times varighed. Guiden blev anvendt som skabelon, der gjorde plads til, at den enkelte underviser kunne opholde sig længere i et emne, der lå underviseren særligt på sinde. Vi var åbne over for de begreber og værdier, som underviseren begrundede sin praksis med og stillede åbne spørgsmål omkring emnerne og anvendte underviserens egne svar og formuleringer som afsæt for den videre samtale.

Interviewguiden stiller spørgsmål indenfor følgende emner:

Din faglige baggrund og undervisningsopgaver

Din konkrete praksis i undervisning og evaluering

Din forståelse af entreprenørskabsbegrebet og værdi i entreprenørskab

Din oplevelse af udfordringer

Din beskrivelse af former for underviserautoritet

Din oplevelse af entreprenørskab i relation til kolleger og fagmiljø

Dine perspektiver for entreprenørskabsundervisning på universitetet

Figur 1: Interviewguide. 
Vi optog interviews på diktafon og behandlingen af materialet forløb derefter sådan, at vi startede med grundig gennemlytning, lavede enkelte udskrifter og gensidige mundtlige præsentation for hinanden. I denne proces ledte vi ikke efter noget specielt, men fandt områder hos hver enkelt underviser, som vi tog notater på. I denne fase lavede vi mindmaps, tegninger og skitser. Herefter begyndte vi at kigge på forskelle fx i undervisernes betoning af værdier og i proces og tegnede modeller, som vi derefter analyserede ved at efterprøve forskelle. Det gjorde vi ved bl.a. at sammenføre underviserens forståelse af entreprenørskab med underviserens beskrivelse af sin undervisningspraksis og kigge på forskelle mellem undervisernes forståelser og praksisformer. På den måde kom vi frem til nogle overordnede temaer og teser vedrørende værdier i udvikling og undervisning, et professionelt selv og et personligt selv samt fag og fagdidaktik i entreprenørskab. Dette analytiske fokus blev brugt til at gå materialet efter igen, og vi fandt dokumentation i hvert enkelt interview på det afgrænsede område. Det videre analysearbejde og gennemskrivningen af analyserne har jeg stået for alene.

I det følgende præsenterer jeg analysen $\mathrm{i}$ kondenseret form og med det hovedsigte at give et indblik i de interviewedes forståelser af entreprenørskabsbegreber, integrationsprocesser, legitimitet, motivation, udfordringer og nye underviserroller. ${ }^{2}$

\section{Entreprenørskabsbegreber i praksis}

Det er karakteristisk for de fem undervisere, at de alle forholder sig eksplicit til begrebet entreprenørskab, som noget, der kommer fra en mere samfundsfaglig og økonomisk orienteret interesse i samfund og udvikling. Det kommer til udtryk ved, at de dels beskriver sig selv gennem en forskel til betydningen af entreprenørskab forstået som iværksætteri, dels ved at underviserne afsøger og finder nogle andre kvaliteter ved begrebet. De taler bl.a. om nye 'gørens'-dimensioner i dannelse og en ny type af akademikere som 'kapable borgere'.

I praksis forstår underviserne noget vidt forskelligt ved entreprenørskab. Deres forståelser spænder fra entreprenørskab forstået som et didaktisk redskab i et bredt og alment pædagogisk fokus på 'at lære de studerende at lære' - til entreprenørskab forstået som en integreret tværfaglighed, hvor processen og betydningsskabelse er mål.

\footnotetext{
${ }^{2}$ Denne artikel er en kondenseret udgave af undersøgelsen. Artiklens rammer giver ikke mulighed for at præsentere alle analysens pointer eller medbringe understøttende og tydeliggørende citater fra de deltagende undervisere. En langt mere udfoldet analyse af undersøgelsen med citater fra interviews kan læses i Udvikling af undervisning og underviserkompetencer - belyst gennem interviews med entreprenørskabsundervisere, Skriftserie fra Center for Undervisningsudvikling og Digitale Medier, Aarhus Universitet, 2013. Artiklen er tilgængelig elektronisk, linket er på referencelisten.
} 

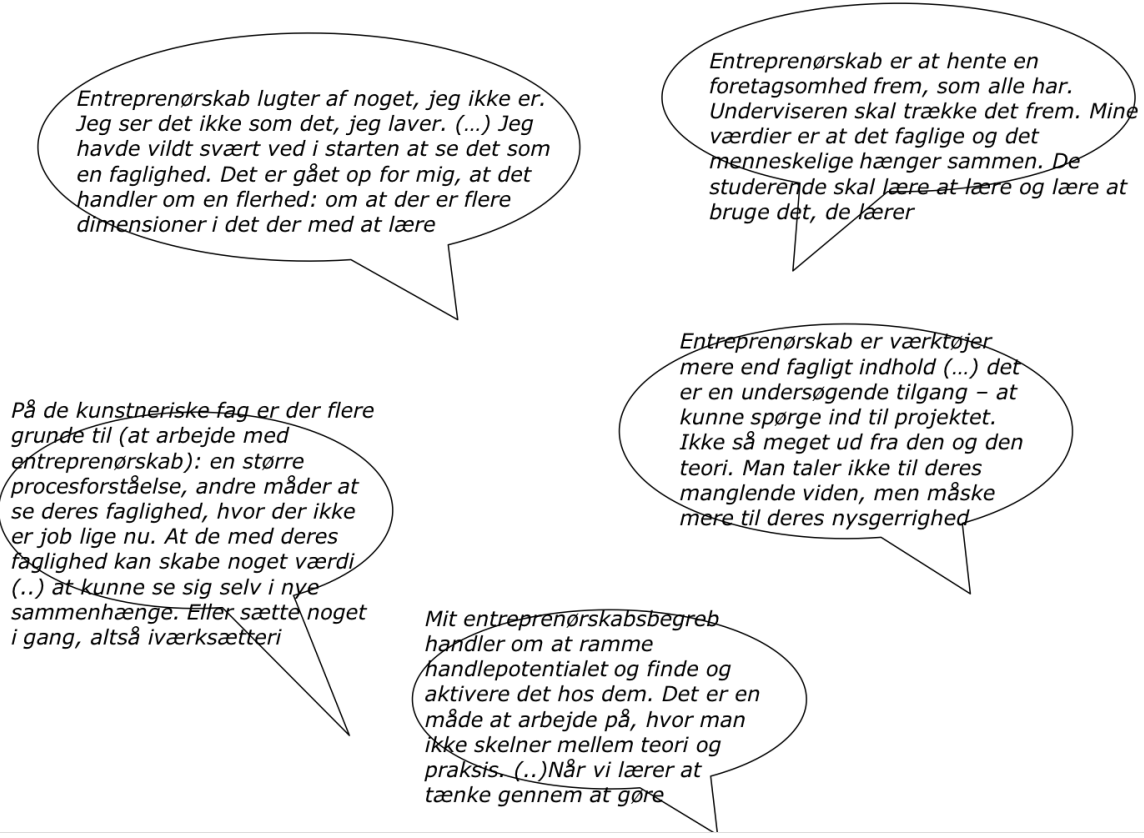

Figur 2: Underviseres beskrivelser af deres entreprenørskabsbegreb.

Underviserne taler således om entreprenørskab som en pædagogisk og didaktisk tilgang og om entreprenørskab som en faglighed i sig selv. Samlet set formulerer underviserne sig om betydninger i entreprenørskab, der knapt nok kan rummes i et og samme begreb. I stedet ser jeg, at de fem undervisere beskriver tre lag af betydninger, og jeg kan kondensere tre forskellige forståelser af entreprenørskab hos de fem undervisere:

- Et alment didaktisk begreb for undervisning, der understøtter proces- og studenterorienterede, aktive læreprocesser.

- Et begreb om værdiskabelse, der forbinder sig til integrerede læreprocesser, hvor den studerende gør sig erfaringer med at anvende sin faglighed i en bred kontekst og styrker en personlig faglig læring gennem kompetencer som handlekraft, tværfagligt samarbejde, proceskompetence og selvindsigt.

- En smallere definition af værdiskabelse forstået som iværksætteri og kompetencen til at anvende sin faglighed i forhold til at skabe værdi og forandring for flere.

De forskellige betoninger af begrebet entreprenørskab kommer til udtryk i undervisernes udsagn om, hvilke værdier de tillægger entreprenørskab i undervisningen for de studerende: Værdierne bliver formuleret som konkrete nuancerer i den personlige læring, i proces- og handlekompetence, i tværfagligt samarbejde og værdiskabelse. Samlet set ønsker underviserne, at de studerende får mulighed for at træne og udvikle nye måder at agere og handle på i deres liv og i samfundet. 
Underviserne er bevidste om de studerende og ser med deres synsvinkel på det faglige arbejde og udtrykker en generel studenterorienteret tilgang til undervisning (Fink, 2003). Men underviserne taler også om de studerendes studieprocesser og om deres handlemåder og tilgang til verden generelt som områder, læringsaktiviteterne retter sig imod.

\section{Progression og integration}

Undervisernes beskrivelser kan som nævnt forstås som tre lag af betydning i entreprenørskab, og når jeg kobler de lag sammen med undervisernes ordrette citater om, hvilke læringsmæssige værdier og mål de hver især har for deres entreprenørskabsundervisning, kan undervisernes beskrivelser af betydning, af mål og praksisformer placeres i et skema:

\begin{tabular}{|l|l|l|}
\hline $\begin{array}{l}\text { Didaktik og almene lærepro- } \\
\text { cesorienterede undervisnings- } \\
\text { elementer }\end{array}$ & $\begin{array}{l}\text { Arbejdsformer baseret på } \\
\text { anvendelse af faglighed i } \\
\text { proces- og projektorienteret } \\
\text { arbejde i en åben kontekst }\end{array}$ & $\begin{array}{l}\text { Iværksætteri og værdiskabel- } \\
\text { se }\end{array}$ \\
\hline $\begin{array}{l}\text { At lære, hvordan man lærer at } \\
\text { anvende sin viden }\end{array}$ & $\begin{array}{l}\text { Se sig selv i en anden sammen- } \\
\text { hæng }\end{array}$ & $\begin{array}{l}\text { Integreret tværfaglighed } \\
\text { Intervention og transformation }\end{array}$ \\
\hline At lære, hvordan man læser verden
\end{tabular}

Figur 3: Oversigt over betydningslag i entreprenørskab hos de fem undervisere.

Jeg læser skemaet sådan, at det beskriver en mulig taksonomi og progression i entreprenørielle læringsniveauer fra et didaktisk niveau med almene procesorienterede læreprocesser med mål som at 'lære-at-lære' til mere sammenhængende arbejdsformer i forløb med anvendelse og projektorienteret faglighed med læringsmål som 'at åbne verden', 'se faglighed anvendt i nye sammenhænge', til det mest avancerede taksonomiske niveau, hvor faget iværksætteri og værdiskabelse har læringsmål som 'intervention gennem tværfaglighed'.

På det grundlæggende niveau viser de interviewede undervisere interesse for aktive studenterorienterede læringsformer og finder forståelse og redskaber hertil i den entreprenørielle didaktik. Det læser jeg sådan, at en almen interesse hos undervisere for nye og aktive læringsaktiviteter kan blive inspireret af entreprenørskabsdidaktikken. Jeg ser, at den underviser, der ønsker at arbejde med entreprenørielle læringsformer, starter med (eller har allerede) et læringssyn, der er orienteret imod læreprocesser. 
Den underviser kan på baggrund af sin erfaring med at arbejde med didaktiske elementer i sin undervisning fortsætte med at udbygge sin erfaring med proces- og læringsorienterede forløb og eventuelt udvikle en egentlig faglighed i iværksætteri.

Når jeg ser skemaet som mulige taksonomiske niveauer og sammenholder det med forskning i generiske niveauer i studiekompetence, genkender jeg tre niveauer hos Barrie: den studerende får kompetencer til at tilegne sig viden ('complement'), den studerende oversætter/omsætter og videreudvikler sin viden gennem anvendelse ('translate') og den studerendes handling og forståelse er personligt og fagligt integreret ('enable').

Udover at skemaet kan foreslå en taksonomi for kompetencemål i entreprenørskabsundervisning, kan skemaet opfattes som en beskrivelse af processer i faglig progression, dvs. som processer i integrationen af entreprenørskab i en faglig kontekst. De tre niveauer karakteriserer så tre faser eller grader af integration af entreprenørielle arbejdsformer i faget. I den første fase er det entreprenørielle en didaktisk driver af almene læreprocesser i ethvert fagligt arbejde, i anden fase er det entreprenørielle en avanceret form for projektarbejde, mens det entreprenørielle i den tredje fase er et fag med iværksætteri som mål.

I relation til undervisernes forskellige forståelser, ser jeg skemaet som deres veje ind i en entreprenøriel undervisningspraksis og forstår progressionen i relation til de arbejdsformer, underviserne ønsker at håndtere/kan håndtere hen ad vejen.

Dermed forbinder jeg muligheden for progression og integration af en entreprenøriel faglighed $\mathrm{i}$ et fagfelt med en kompetenceudviklingsproces hos underviseren. For disse undervisere ser det ud til, at kompetenceudviklingsprocessen starter med en alment læringsorienteret didaktik, som kan udvikles gennem en højere og højere grad af faglig integration af entreprenørskab i det faglige felt.

Hvordan de fem undervisere udvikler kompetencer hertil, belyser jeg i det følgende.

\section{Legitimitet og motivation}

Underviserne udtrykker sig meget nuanceret og bruger forskellige betoninger, når de begrunder hvorfor, de ønsker at arbejde entreprenørielt. Betoningerne ser ud til at karakterisere forskelle på i hvor høj grad, det entreprenørielle er integreret med det faglige i den enkeltes undervisning. De formulerer sig om betydninger for både studerende, fag og samfund, og når jeg nærlytter til og nærlæser undervisernes argumentationskæder, ser det ud som om, der er sammenhæng mellem graden af integration, didaktik og faglighed: Underviseren beskriver sin interesses udgangspunkt - i den studerendes læring, i fagets udvikling eller i den samfundsmæssige relevans. 
Alle tre faktorer er i spil hos alle, men nogle undervisere har en vision med deres fag, som de ser, kan realiseres gennem en veludviklet entreprenøriel faglig tilgang, mens en anden har fokus på aktive læreprocesser.

Ud fra længere argumentationskæder i dialogen tegner der sig konturerne af tre forskellige afsæt for underviserens ændring af sin undervisningspraksis. Alle fem undervisere kan placereres indenfor de tre afsæt, som er: Den studerende, faget eller en forståelse af verdens behov. De kan beskrives kortfattet:

- Studerende er på fag, som de skal lære gennem didaktisk tilrettelagte arbejdsmåder for at kunne agere i verden: De studerende er den væsentligste årsag til at arbejde på en anden måde, de studerendes læring justerer undervisningsformerne, og hvor de studerendes udgangspunkt fastholdes, er en faglig integration af entreprenørskab i faget en vag horisont. Entreprenørskab tjener en aktiv og involverende læreproces. Skemaets første trin med fokus på didaktik og læreprocesser karakteriserer praksisformerne i undervisningen her.

- Faget ser på verden, det kalder på en didaktik med henblik på den studerendes læring og evne til at interagere: Det faglige er udgangspunkt for analyse af verden og det analytiske og verden kobles sammen i en didaktik. Her ligger muligheden for dyb faglig udvikling, hvor faglig forståelse og værdier er i centrum. De konkrete undervisningsformer ligger i skemaets midterfelt, hvor arbejdsformer og forløb undersøger virkelige problemstillinger. De kan udvikles i retning af skemaets tredje felt, hvor den faglige vinkel på verden er fuldt integreret som fag.

- Verden kalder på en faglig didaktik med henblik på den studerendes handlen: Analysen af verden er der på forhånd og skal formidles til de studerende, som skal godkende analysen, før den kan realiseres som didaktik. En model med mulighed for didaktisk innovation, hvis analysen af verden tilhører faget og fagfællesskabet. Undervisningspraksis ligger i skemaets tredje felt, hvor iværksætteri er en integreret faglighed.

Begrundelserne for at arbejde entreprenørielt i undervisningen går som beskrevet på en akse fra at lære de studerende at tage ansvar for sig selv ('lære at lære' og 'at lære af fejl') til, at undervisernes værdier for faget og for uddannelse går op i en didaktisk helhed med deres syn på samfundets udvikling.

Betydningslagene fortæller, at undervisernes praksis er forbundet med deres dybe faglige værdier og deres forståelse af, hvordan uddannelse i deres fag spiller en samfundsmæssig rolle. En ændring af undervisningspraksis er motiveret af og forbundet med underviserens personlige forståelse og værdier, enten for den studerende, for 
faget eller for verden. Dermed er det dybden i ændringer i underviserens forståelse, der skal bære forandringen af praksis. Og praksisændringen skal føre til nye dybe forståelser, for at forandringen bliver vedvarende.

\section{'Genforhandling' og integration}

En entreprenøriel udvikling af undervisningsformer sker hos de involverede undervisere gennem den enkeltes aktive 'genforhandling' med sit fag og dets aktuelle relation til det samtidige samfund, gennem underviserens pædagogiske forståelse af læring og af den konkrete studerende og gennem underviserens personlige udfyldelse af sin professionelle rolle som underviser.

Det er en omfattende 'genforhandling', som jeg vil sammenligne med en integreret læreproces, hvor den lærende - i dette tilfælde underviseren - åbner sin store bagage af forståelser, viden og kundskaber (Illeris, 2007). Den type læreprocesser er krævende både på et professionelt og et personligt plan og i særlig grad, fordi læreprocessen finder sted samtidig med, at undervisningen kører.

Det kan være med til at forklare, at hver enkelt underviser taler meget om legitimiteten $i$ at arbejde entreprenørielt og kobler den sammen med den enkeltes motivation for at undervise på nye måder. Den personlige motivation er baseret på en personlig og professionel klangbund af viden og værdier og den personlige erfaring med handlinger, der knytter sig hertil.

\section{En faglig og personlig motivation}

I samtalerne kommer der udsagn frem, som vidner om, at den enkelte underviser investerer sig på et mere end fagligt niveau. Der er en personlig værdi på spil, som driver underviseren og som rækker ud over en personlig faglig interesse.

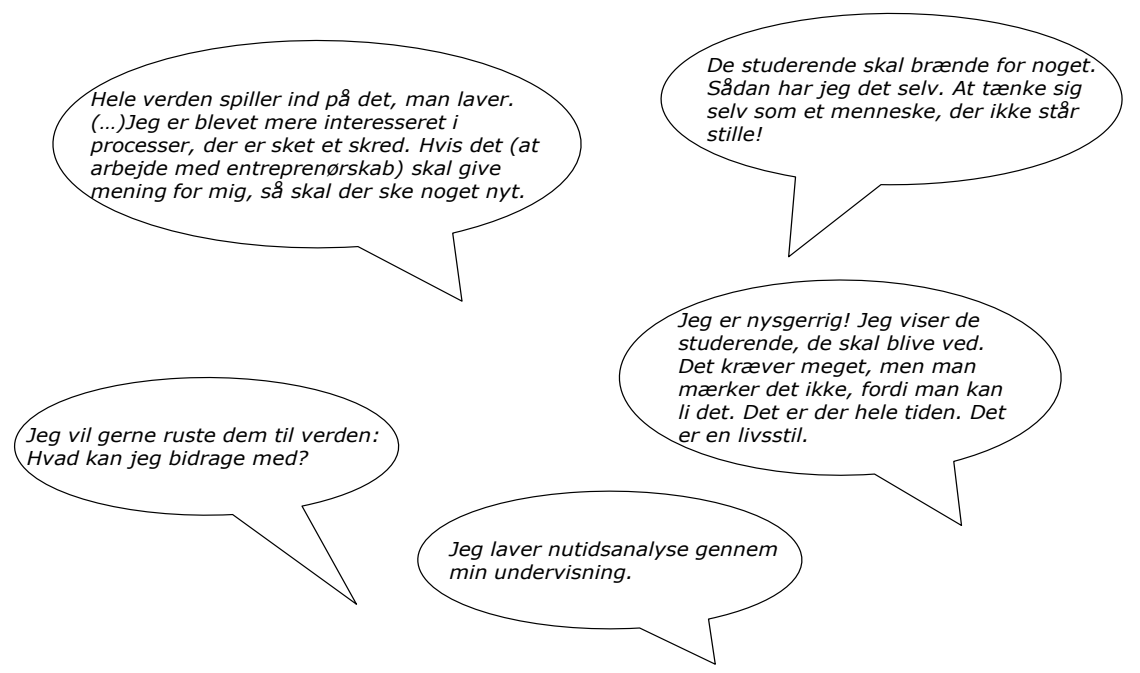

Figur 4: Undervisernes personlige og faglige motivationer. 
De personlige bevæggrunde og værdier viser, at underviseren er personligt delagtig i læreprocesserne, hvor udvikling af entreprenørskab bliver til en professionel udviklingsproces for underviseren: Gennem en internaliseringsproces kobler underviseren sin viden og kunnen sammen til nye praksishandlinger i undervisningen.

Det er en proces, hvor underviseren kommer til syne for sig selv med forstærkede eller reviderede værdier og forståelse. De deltagende undervisere er bevidste om, at de gør noget i deres undervisning, som adskiller dem fra fagfæller og kolleger. De formulerer sig om, at deres praksis rummer forståelser af faget og af de studerendes læreprocesser, som er forskellig fra deres kollegers praksis og forståelse. Flere siger direkte, at kollegernes undervisning er meget forskellig og rummer nogle helt andre værdier, som det er deres faglige ret at have. Ingen diskuterer løbende deres undervisningspraksis og praksisformers værdi med andre kolleger end deres eventuelle medundervisere.

\section{Udfordringer}

Underviserne bruger ord om deres udfordringer, som vidner om, at der er mere end faglighed på spil.

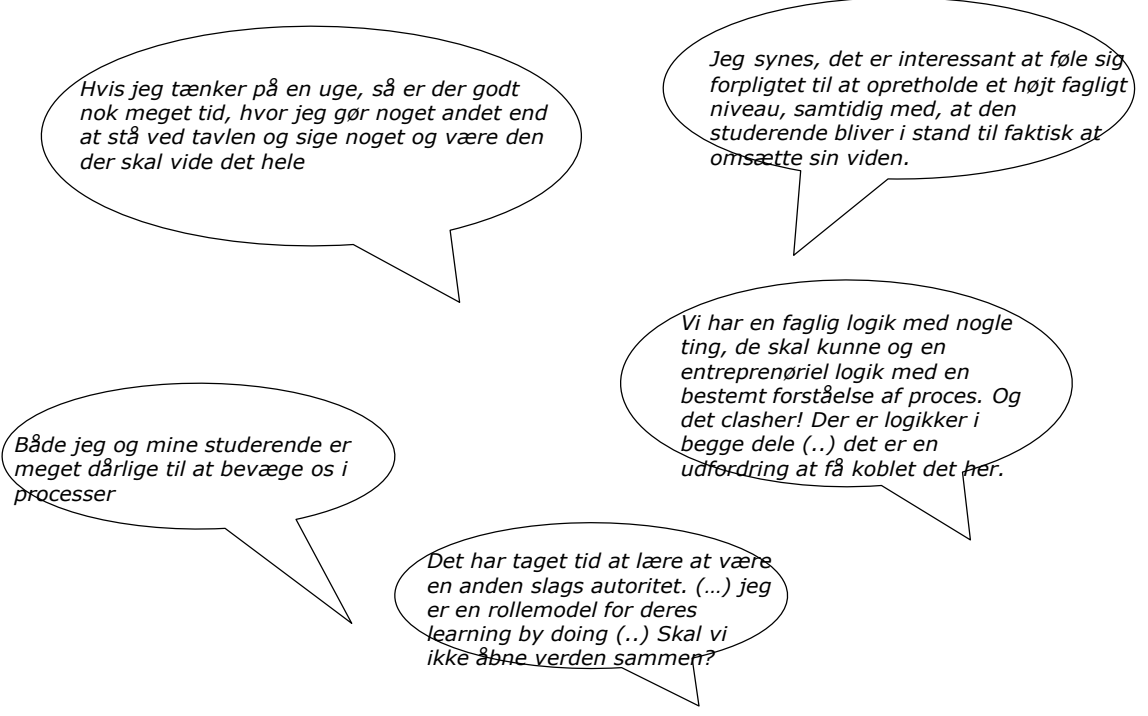

Figur 5: Underviseres udsagn om udfordringer.

De formulerede udfordringer involverer personlige erfaringer og kompetencer, og de drives og genereres af mere end faglighed i snæver forstand. For eksempel er det personlige kompetencer og erfaringer, der skal støtte underviseren i forhold til at udholde den type usikkerhed, der er forbundet med 'clash' mellem forskellige logikker. Der er også tale om personligt faglige udfordringer, hvor fag og personlig forståelse og handling inden for faget er under forandring, fx hos den underviser, der ser sig som rollemodel i forhold til opgaven 'at åbne verden sammen'. 
En af de store udfordringer er integration af den nye faglige dimension indenfor kernefaget. Det er gennem integration, at den faglige legitimitet fremkommer og giver underviseren en mindre usikker platform at stå på. Men udfordringen formuleres også som det at 'være i proces', at processer (vejen) er mål i sig selv. Det er uvant for både studerende og underviser og medfører usikkerhed, som underviseren skal håndtere - og træne de studerende $\mathrm{i}$ at håndtere. Både studerende og underviser skal lære at være i en arbejdsproces, hvor det ikke er til at forudse, hvad arbejdsprocessen resulterer i. Den akademiske arbejdsmåde udvides til at foregå som en proces, der er medbetydende for resultatet, og hvor proces og produkt ikke kan adskilles.

Den arbejdsform er styret af proces og motiveret af situationsbestemte og relationsbetingede og fagrelaterede logikker i en given arbejdsgruppe og opgave (Wenger, 2012). Det kræver, at de involverede i arbejdsprocessen kan veksle mellem en traditionel ydre styring af opgaven og indre styrede processer i samarbejdet og genkende og anvende både faglige og processuelle resurser.

Underviseres autoritet og legitimitet forandres, og det reflekterer underviserne over.

\section{Nye underviserroller}

Underviserne taler om, at deres funktion veksler mellem at være den, der sætter rammen og ved hvorfor, og den, der undersøger og åbner data på lige fod med de studerende. Der ligger et skift for underviseren i forhold til at befinde sig i sit forskningsområdes sikre viden, underviserens substantielle faglighed, hvor underviseren er 'foran' og viser vej, over for de processuelle aktiviteter, der er mere orienterede mod de studerendes faglige og sociale engagement, og hvor undervisere er 'bagved' og samler processen (Cornelius-White \& Harbaugh, 2010). Der er flere autoriteter på spil, og både studerende og underviser skal kunne se forskel og genkende funktionerne.

Alle undervisere taler om forandrede roller og nye former for autoritet, og indirekte beskriver de, hvilke kompetencer en entreprenøriel underviser, ifølge deres erfaringer, har brug for at udvikle. Underviserne har selv hen ad vejen udviklet eller er i gang med at udvikle redskaber på en lang række områder, som der kan være gode grunde til at arbejde langt mere systematisk med i pædagogisk kompetenceudvikling. Det drejer sig primært om at have adgang til redskaber og kendskab til en variation af øvelser, om kompetencer til at reflektere over praksis og evne til at samarbejde. Herudover nævner underviserne kompetencer inden for: 'Processtyring', 'anerkendende dialog' og 'selvrefleksion'.

Når vi taler om entreprenørskab som en ny faglig dimension i undervisningen, bliver entreprenørskab et koblingspunkt mellem fag, processer, nye læringsrum - og personlig stil i undervisning og autoritet for underviseren. For at få koblingerne til at fungere kræver det også kompetence til selvrefleksivitet og korrektion i den konkrete situation. 


\section{Diskussion og konklusion: Motiverende rammer for faglig nyudvikling}

Trods interviewundersøgelsens spinkle empiriske grundlag giver den et indblik i, hvordan motivation er omdrejningspunkt i de fem humanistiske underviseres didaktiske og faglige udvikling. Disse underviseres udvikling af undervisning inden for entreprenørskab og innovation er koblet til personligt integrerede læreprocesser og motivation. I forlængelse heraf kunne det være interessant at undersøge, hvordan undervisere på andre fagområder integrerer entreprenørskab i deres faglighed og sammenligne faglige udviklingsprocesser inden for entreprenørskab på tværs af videnskabsområder/fakulteter: Hvordan spiller fagets metoder og tilgange ind på faglige udviklingsprocesser?, og hvilke roller spiller underviseren i faglige udviklingsprocesser? Tilsammen kunne sådanne undersøgelser være med til at kvalificere: Hvilke rammer udvikler 'enabled' og 'embedded' underviserkompetencer og er motiverende for vedvarende faglig nyudvikling på universiteterne.

Lene Tortzen Bager, ph.d. og lektor ved Center for Undervisningsudvikling og Digitale Medier, Aarhus Universitet og selvstændig med firmaet tortzen.bager - platform for videreudvikling af kompetencer, kvalitet og kultur i uddannelser. http://tortzen-bager.dk.

\section{Litteratur}

Bager, L. T. (2013). Udvikling af undervisning og underviserkompetencer i praksis - belyst gennem interviews med entreprenørskabsundervisere, skriftserie ved Center for Undervisningsudvikling og Digitale Medier, Aarhus Universitet. http://tdm.au.dk/fileadmin/tdm/Publikationer/CUDiM_2__Udvikling_af_undervisning_og_underviserkompetencer_i_praksis__Lene_Tortzen_Bager_2013_-_webudgave.pdf

Bager, L. T. \& Blenker, P. (2008). Bevidsthed om læring - en kompetence med udgangspunkt $i$ entreprenøriel læring, arbejdspapir fra CFU, Aarhus Universitet. http://tdm.au.dk/fileadmin/www.humaniora.au.dk/center_for_undervisningsu dvikling/publikationer/arbejdspapirer/bevidsthedomlaering.pdf

Barrie, S. (2002): http://www.itl.usyd.edu.au/graduateattributes/ISL_gradatt.pdf

Cornelius-White, J. H.D. \& Harbaugh, A. P. (2010). Learner-centered instruction. Thousand Oakes, CA: Sage.

Fink, L. D. (2003). Creating significant learning experiences. San Francisco: Jossey-Bass.

Fonden for Entreprenørskab/Young Enterprise Danmark (2013a). Fra ABC til ph.d.: http://www.ffe-ye.dk/media/203127/fra_abc_til_phd_2012.pdf

Fonden for Entreprenørskab/Young Enterprise Danmark (2013b). Progressionsmodel: entreprenorskabs- og innovationsundervisning: http://www.ffeye.dk/videncenter/progressionsmodel

Hargreaves, A. \& Fink, D. (2012). Sustainable leadership. San Francisco: Jossey-Bass. Illeris, K. (2007). Læringens teorier, Roskilde Universitetsforlag.

Moberg, K.(2013). Præsentation på Århus Erhvervsakademi af forskningsresultater fra rapporten: http://www.ffe-ye.dk/media/228566/effektmaaling_2012.pdf 
Wenger. E. (2012). En social teori om læring. In: K. Illeris (red.): 49 tekster om læring. Frederiksberg: Samfundslitteratur.

Wenger. E. (2004). Communities of practice -a brief introduction, Oregon University. https://scholarsbank.uoregon.edu/xmlui/bitstream/handle/1794/11736/A\%20bri ef\%20introduction $\% 20$ to $\% 20$ CoP.pdf?sequence $=1$ 